\title{
The effect of omalizumab on eosinophilic inflammation of the respiratory tract in patients with allergic asthma
}

\begin{abstract}
Bronchial asthma is characterised by high levels of immunoglobulin $\mathrm{E}(\mathrm{lg} E)$ and overproduction of pro-inflammatory cytokines, including interleukins IL-4, IL-13 and IL-5 needed for, amongst other things, the production of IgE and the differentiation, maturation, migration and survival of eosinophils. Eosinophils are one of the most important cells in allergic inflammation. Their presence in tissue is linked to the persistence of inflammatory infiltrate, tissue damage and remodelling. Although these cells are very sensitive to corticosteroids, some asthmatic patients do not respond to high doses of these drugs, even when administered systemically. Transbronchial biopsies and bronchoalveolar lavage performed in patients with steroid-resistant asthma have demonstrated higher levels of eosinophils and Th2-type cytokines (IL-4 and IL-5) compared to steroid-sensitive patients. Clinical studies have confirmed that the very effective treatment in these cases is therapy with omalizumab — an anti-lgE monoclonal antibody. The paper discusses the efficacy of omalizumab in reducing eosinophil number in peripheral blood and in the airways of asthmatic patients based on basic, clinical, observational studies and case reports. The significance of omalizumab therapy in asthma control and mechanisms that regulate the effects of omalizumab on eosinophils are evaluated.
\end{abstract}

Key words: allergic asthma, omalizumab, eosinophilic inflammation, eosinophils

Pneumonol Alergol Pol 2016; 84: 232-243

\section{Introduction}

Asthma is an illness characterized by bronchial hyperreactivity, chronic inflammation and structural changes in the airways. Its pathogenesis involves a large number of cells and inflammatory mediators. Patients with bronchial asthma usually demonstrate high levels of immunoglobulin E (IgE) and overproduction of pro-inflammatory cytokines, including interleukins IL-4, IL-13 and IL-5, which are needed for, amongst other things, the production of IgE and the differentiation, maturation, migration and survival of eosinophils. Mast cells, basophils, eosinophils, and lymphocytes play important role in the development of allergic inflammation. Apart from the inflammatory cells, a significant role in the chronic phase is granted to structural cells such as epithelial cells, myocytes and fibroblasts. Among the many mediators of allergic reactions, the $\mathrm{IgE}$ molecule is regarded as playing a key role in this process. It is a leading element in the early stage of an allergic reaction as it initiates mast cell degranulation. It also participates as an immunoregulator in the late phase of the allergic reaction and mediates the development of eosinophilic inflammation. IgE is also believed to play a role in the remodelling that occurs in the airways [1]. Burrow et al. [2] report that a high level of IgE in plasma represents a risk factor for the development of bronchial asthma, and Kovac [3] and Carroll [4] also note that it correlates with the degree of severity. Hence immunoglobulin E represents a significant target for drugs used for treating asthma.

\footnotetext{
Address for correspondence: Izabela Kupryś-Lipińska Medical University of Lodz, Department of Internal Medicine, Asthma and Allergy, e-mail: ikuprys@wp.pl DOI: 10.5603/PiAP.2016.0029 


\section{Pharmacodynamic properties of omalizumab}

The only drug currently used for the biological treatment of bronchial asthma with anti-IgE activity is omalizumab - a humanised monoclonal antibody created by recombining the DNA of Chinese hamster ovary cells, of which 95\% of the sequence of omalizumab is in accordance with that of human immunoglobulin class G1. The medicine acts by selectively binding with free IgE molecules at the $\mathrm{C} \varepsilon 3$ domain. The formed IgE-drug complex prevents IgE binding to FCe RI receptors, which have a high affinity for IgE, on mast cells and basophils. By doing so, it prevents the degranulation of these cells depending on the specific cross-linking of the allergen IgE bound to FceRI presented on the surface of these cells. Omalizumab does not bind the IgE molecules which are already complexed with the receptor, nor does it directly connect with IgE receptors, which avoids the harmful activation of mast cells and basophils [5].

The neutralisation of free $\operatorname{IgE}$ results in blocking the allergic reaction cascade by specific allergens at the level of mast cell and basophil activation, and as a consequence, preventing the development or reducing the allergic inflammation in the respiratory tract. Most importantly, omalizumab blocks the binding of IgE with FceRI localized on other cells, e.g. dendritic cells and this way affects the presentation of the allergen to Th2 lymphocytes, and on eosinophils, monocytes and airway epithelial cells, where the receptors probably perform a regulatory function. In addition, omalizumab blocks binding of $\operatorname{IgE}$ to specific receptors of low affinity (FceRII), found on B and T lymphocytes, eosinophils, macrophages, dendritic cells and other cells involved in the development of chronic inflammation, thus trapping the allergen and presenting it to the $\mathrm{T}$ lymphocytes [6].

Apart from neutralising free IgE, long-term omalizumab therapy results in the reduction of IgE production by B lymphocytes. A theoretical model based on estimates from the results of the INNOVATE study calculated that 5-year omalizumab treatment leads to the normalisation of the total production of IgE [7]. An important role in this phenomenon is played by Th2-lymphocytes and by IL-4 and IL-13 produced by Th2-lymphocytes [6]. Omalizumab was confirmed to reduce the amount of IL-4 [8] and IL-13 [9] positive cells and B lymphocytes in bronchial tissue [8].

Apart from direct effects of omalizumab on $\operatorname{IgE}$ and the regulation of IgE production, a signi- ficant element of the pharmocological efficacy of omalizumab is its ability to indirectly modulate the course of allergic inflammation. For example, it decreases the expression of FCERI receptors on mast cells, basophils and dendritic cells. Bronchial bioptates from asthma patients, independent of atopic status, and from atopic controls found a greater number of cells presenting FceRI on their surface (mainly mast cells and macrophages) compared to healthy subjects without signs of atopy [10]. Particularly high expression was found in bronchial tissue taken from patients who had died during the course of a severe acute asthma attack [11]. It is known that FceRI expression on effector cells correlates with IgE concentration in serum and is dependent on the stimulation of these receptors through the IgE molecules bound to them. Most importantly, the binding of IgE to a receptor stabilises both IgE and the receptor [1, $6,12]$. Omalizumab therapy quickly reduces the availability of free IgE to form complexes with the receptors (by 96\% in three days) [13], and by doing so, inhibits the intracellular signalling from these receptors activating the synthesis and expression of these receptors on the cell surface.

It has been shown that 16 -week omalizumab therapy significantly reduces the number of IgE-positive and FceRI-positive cells in the bronchial submucosa [8]. As noted by Lin et al. [13], this inhibition of Fce RI expression on basophils can be seen after seven days from omalizumab administration, and as MacGlashan et al. [14] demonstrated, three months following the commencement of treatment, the inhibition effect is $96 \%$. Chanez et al. [15] made a similar observation; the FceRI expression on basophils after 16 week-therapy with omalizumab decreased by $83 \%$. A study conducted by Saini et al. [16] revealed that discontinuation of omalizumab therapy results in a gradual increase of FceRI density on basophils simultaneously to the free IgE in serum, which confirms the active role of omalizumab in the inhibition of this receptor on basophils.

A decrease in the FceRI expression on basophils plays a functional role. It is associated with a lower histamine release, being a consequence of specific stimulation of basophils with an allergen but also a consequence of cellular lysis [17-19].

Besides, patients treated with omalizumab demonstrated a reduction of the number of peripheral basophils [20]. IgE is also believed to control homeostasis of human basophils. Omalizumab similarly affects mast cells. However, this phenomenon occurs more slowly than for basophils and is associated with reduced skin 
response to an allergen in skin prick tests [21]. Omalizumab therapy did not decrease the number of tryptase-positive cells in the skin.

Also the FceRI expression on the surface of dendritic cells depends on the presence of IgE in the microenvironment. Prussin et al. observed that after 7 days following the commencement of omalizumab therapy the FceRI expression on precursors of dendritic cells, both of myeloid and lymphoid origin, is reduced [22]. The decrease in the FceRI expression on dendritic cells correlated with the decrease in its expression on basophils. Chanez et al. [15], who conducted similar studies on precursor of plasmacytoid dendritic cells, made similar conclusions. However, he did not find a correlation between decreased FceRI expression and clinical parameters [15]. Feuchtinger et al. [23] observed normalization of the number of dendritic cells in grass pollen season in patients with pollinosis allergic to grass, who underwent specific immunotherapy and were also administered omalizumab. The reduced number of dendritic cells and the FceRI expression on their surface potentially reduces the presentation of allergens to specific lymphocytes, thereby, decreasing their clonal activation. It might reduce polarization of native Th to Th2 and production of Th2 cytokines contributing to the development of allergic inflammation.

Eggel et al. [24] in their study revealed that omalizumab not only neutralizes free IgE and decreases expression but also might accelerate dissociation of IgE from FceRI on basophils. This observation was confirmed by Serrano-Candelas et al. [25] on mast cells. They also proved that this phenomenon is associated with IgE-dependent decreased signalling from FceRI, connected with inhibition of proximal phosphorylation in the Syk-LAT-PLC $\gamma$ axis, as well as inhibition of degranulation and synthesis of leukotrienes.

Neutralization of free IgE by omalizumab and its effect on the expression and function of Fc $\varepsilon$ RI are reflected in clinical phenomena, such as inhibition of early [26, 27] and late phase of allergic reaction $[28,29]$ and also a decrease in the severity of chronic allergic inflammation.

Boulet et al. [26] conducted omalizumab therapy in patients with allergic asthma. They observed that on day 27 they had to administer a bigger than a double dose of allergen concentration in inhaled provocation in order to decrease $\mathrm{FEV}_{1}$ ( forced expiratory volume in 1 second) by $15 \%$ (PC15 for the allergen) in the early phase of asthmatic reaction to the allergen.

Zielen et al. [27] in their study reported that omalizumab therapy at 8 and 16 week significan- tly inhibited post-allergenic bronchial contraction within $30 \mathrm{~min}$. following the provocation and reduced the FeNO (fractional nitric oxide concentration in exhaled breath) level measured 24 hours after bronchial provocation with an allergen, which implies inhibition of eosinophilic influx to the allergic reaction site in the late phase. This observation was confirmed by a study conducted by van Rensen et al. [29], who noted that a 12week omalizumab therapy inhibits early and late phases of asthmatic reactions after allergen challenge. This phenomenon was accompanied by a decrease in eosinophilic infiltration in bronchial bioptates, collected after 24 hours following the provocation.

Due to constant or frequent exposure to a particular allergen, the late phase may turn into chronic inflammation (with remodelling) and lead to chronic dysfunction of the organ or system; and in the case of the bronchi - to the development of chronic bronchial asthma.

Conversion of the late phase of an allergic reaction into a chronic inflammatory process still has not been clearly explained but mastocytes and eosinophils seem to play a key role in this process. Both populations play a role of effector cells. They coexist in tissues in the late phase of an allergic reaction and in the development phase of chronic inflammation and they probably maintain the inflammatory response. It was proved that both the populations can mutually affect their biological activity through released cytokines and a direct cell-to-cell (ligand-receptor) contact. This interaction is strong and protects eosinophils against dexametazone-induced apoptosis [30]. Thus, the modulation of the number of both cellular populations, their functions and mutual interactions in the inflammatory infiltrate seems to be highly important in the control of chronic inflammation associated with asthma. Especially that asthmatic patients demonstrate an increased number of eosinophils in bronchial bioptates independent of atopia status in comparison to controls [31]. The number of mast cells in a study conducted by Macfarlane et al. did not significantly differ between asthmatic patients and healthy controls, whereas the number of basophils was significantly higher in patients with atopic asthma but was not significantly different from the one observed in the inflammatory infiltrate in patients with non-atopic asthma [31].

It has been confirmed that omalizumab decreases the degree of chronic inflammation in the bronchi in asthmatic patients, probably by affecting eosinophils. Djukanovic et al. revealed 
that 16-week omalizumab therapy decreased the percentage of eosinophils in induced sputum and tissue bioptates as well as decreased the number of CD3+, CD4+, CD8+ cells, B lymphocytes and IL-4-positive cells [8] ${ }^{8}$. Van Rensen et al. [29] confirmed a considerable impact of omalizumab on tissue eosinophilia. In this study, 12-week omalizumab therapy contributed to a decrease in the number of eosinophils in induced sputum and a decrease in the eosinophilic infiltrate in bronchial tissue bioptates after allergen provocation. Besides, the researchers observed less cells presenting FceRI and CD4+ lymphocytes.

Administration of omalizumab affects not only the number but also the function of eosinophils and lymphocytes. Noga et al. [9] observed in their study that 12-week omalizumab therapy increased eosinophilic apoptosis and decreased the number of $\mathrm{T}$ lymphocytes producing GM-CSF (granulocyte-macrophage colony-stimulating factor), IL-2 and IL-13 in peripheral blood. They did not observe differences with regards to the number of lymphocytes producing IL-5, IFN- $\gamma$ and TNF- $\alpha$.

Inflammation-induced tissue damage is accompanied by reparative processes which lead to airway remodelling. Roth et al. [32] observed that IgE increases airway remodelling in asthma by activation of proliferation of smooth muscle cells as well as by increased extracellular deposition of pro-inflammatory collagen (Types: I, III, VII) and fibronectin. Such findings imply a potential role of omalizumab in airway remodelling. Zietkowski et al. [33] noted that omalizumab therapy at 16 and 52 week following its commencement significantly reduces the level of endothelin-1 (ET-1) in exhaled breath condensate which correlates with a decrease in the FeNO level, eosinophil number in peripheral blood and the ECP (eosinophil cationic protein) level in serum. ET-1 plays an important role in the inflammation of the respiratory tract in asthmatic patients, particularly in the development of severe bronchial hyperreactivity and bronchial remodelling, by activating proliferation of smooth muscle cells and by stimulating subepithelial fibrosis. Roth et al. [34] observed that administration of omalizumab inhibited proliferation of smooth muscle cells, stimulated in in vitro with the serum collected from patients with allergic asthma as well as decreased deposition of type 1 collagen and fibronectin. Moreover, omalizumab affected the function of myocytes by inhibiting IgE-dependent synthesis and secretion of pro-inflammatory cytokines (lL-4, IL-6, IL-8 and TNF- $\alpha$ ) [35]. Huang at al. [36] noted inhibited production of TGF- $\beta$ and pro-inflammatory cytokines (IL-4, IL-13 and TNF- $\alpha$ ) by airway epithelial cells, stimulated by IL-1 $\beta$ and allergen. Hoshino et al. [37] studied a clinical effect of omalizumab with regards to the remodelling process by using high-resolution CT (computed tomography) of the thoracic cavity. A follow-up examination performed after 16 weeks demonstrated thinner bronchial wall in patients with severe asthma, treated with omalizumab. It correlated with improved values of spirometry $\left(\mathrm{FEV}_{1}\right)$ and a decreased number of eosinophils in induced sputum.

The clinical efficacy of omalizumab in the control of chronic bronchial asthma has been confirmed in many clinical studies and meta-analyses [5]. In 2002, this drug was registered to be administered in therapies of uncontrolled moderate and severe asthma in Australia; in 2003 in the United States of America and in 2005 in the European Union as an add-on therapy to high doses of inhaled corticosteroids in combination with long acting $\beta 2$-agonists (LABA) in patients with frequent exacerbations and in 2014 in the treatment of spontaneous persistent urticaria.

The investigators of a 28-week randomized, double-blind and placebo-controlled study, called INNOVATE [38], evaluated the efficacy of omalizumab in a group of patients with severe asthma, in whom the disease control was not achieved after administration of high doses of inhaled corticosteroids in combination with LABA. Part of the studied patients (60\%) took the third drug controlling asthma. Of this percentage, $22 \%$ took oral corticosteroids. Adding omalizumab to the optimized therapy decreased the frequency of significantly clinical exacerbations by $26 \%$, the frequency of severe exacerbations by $50 \%$ and the frequency of emergency medical interventions by $44 \%$. Besides, omalizumab improved the quality of life, morning PEF (peak expiratory flow) value and decreased asthma symptoms. On the base of the INNOVATE study the researchers concluded that the omalizumab therapy should be carried out in 2.7 patients (NNT, number needed to treat) in order to prevent one clinically significant exacerbation, in 2.0 patients to prevent one severe exacerbation. So as to prevent a single medical intervention, the omalizumab therapy should be carried out in 2.8 patients [39].

Meta-analysis of 25 clinical studies [40], conducted in 2014 by Cochrane experts, based on studies where omalizumab was administered to patients with moderate and severe bronchial asthma, demonstrated that the drug was effective 
in reduction of exacerbations and hospitalisations due to exacerbations. It also implies that patients taking omalizumab can reduce doses of the drug or even discontinue the therapy with inhaled corticosteroids more frequently in comparison to the placebo group, whereas patients who were administered long-term therapies with oral corticosteroids, demonstrate better asthma control when they received omalizumab; however, the steroid-sparing omalizumab effect requires further prospective studies.

A pooled analysis of 6 studies, conducted by Chipps et al. [41], evaluating the effect of omalizumab therapy on the quality of life of patients with severe uncontrolled asthma, revealed a significant improvement in limiting activities due to the disease, emotions, symptoms and exposure to environmental factors in the group of patients treated with omalizumab in comparison to patients who were administered optimized pharmacological treatment.

The authors' own experience confirms considerable benefits from omalizumab therapy in patients with severe allergic asthma, including better asthma control and better quality of life, reduced frequency of exacerbations and reduced degree of exacerbations as well as decreased oral corticosteroid demands [42].

Currently, omalizumab is recommended by GINA (global initiative for asthma) experts in patients with moderate and severe bronchial asthma at the $5^{\text {th }}$ stage of the therapy, before oral corticosteroids have been permanently administered [43].

\section{The role of eosinophils in bronchial asthma}

Eosinophils are key inflammatory infiltration cells of the late-phase allergic reactions and chronic inflammatory process in bronchial asthma. Their presence in the tissues is associated with persistence of the inflammatory infiltrate, tissue injury and remodelling [1]. Eosinophils are formed in bone marrow from eosinophil/basophil colony forming units (Eo/B-CFU). IL-3, IL-5 and GM-CSF play a vital role in the differentiation, maturation and migration of eosinophils out of the bone marrow into the circulation, with IL-5 being the most important and most specific for eosinophils at this stage of their development. These hematopoietic cytokines are produced at the site of allergic reaction and endocrinally exert impact on the bone marrow. It has been shown, however, that activated $\mathrm{T}$ cells can also migrate to the bone marrow and locally secrete
IL-5. Eosinophils migrate with blood to the sites of the ongoing inflammation as they are attracted by chemotactic factors: eotaxins, MCP5 (monocyte chemotactic protein 5), MIP1 $\alpha$ (macrophage inflammatory protein- $1 \alpha$ ) and RANTES (regulated on activation , normal T-cell expressed and secreted). IL-4, IL-13, IL-1 and TNF facilitate eosinophil migration from blood to the inflammatory tissue and increase the expression of adhesion molecules on endothelial cells.

Eosinophils, at the site of inflammation, are activated by cytokines, leukotrienes and complement components and release pro-inflammatory mediators responsible for the influx and activation of other inflammatory cells and processes of tissue damage and regeneration. They include enzymes (elastase, collagenase), cationic proteins (major basic protein - MBP), eosinophil peroxidase (EPO), ECP; free radicals and reactive oxygen species, platelet-activating factor (PAF), leukotrienes and numerous cytokines (such as IL-3 and IL-5, GM-CSF, SCF, IL-4 and IL-13, IFN- $\gamma$, eotaxin, RANTES and TGF- $\beta$ ) [1].

The presence of eosinophils in the cell infiltrate in the bronchi is a characteristic feature of the inflammation in asthma patients. The results of studies showing a correlation between the concentration of ECP and the severity of the latephase asthmatic reaction are the evidence for the active role of eosinophils in the development of the late-phase asthmatic reaction [44].

It was further indicated that the number of eosinophils in sputum (reflecting the severity of inflammation in the bronchial tissue) closely correlates with asthma severity as well as the risk and severity of exacerbations [45]. In patients with recurrent asthma exacerbations, anti-inflammatory treatment based on the result of induced sputum cytology with the assessment of the presence of eosinophils was more effective than that carried out on the basis of symptoms and lung function [46]. Eosinophilic airway inflammation in asthma is usually accompanied by mild eosinophilia in peripheral blood, although eosinophilia in the tissues, nasal secretions, sputum and bronchoalveolar lavage (BAL) is usually significantly higher [47].

Eosinophils are very sensitive to corticosteroids. Corticosteroids are considered to be the strongest anti-inflammatory drugs in asthma and in an inhaled form are recommended in all types of chronic asthma [44]. However, there is a group of asthmatic patients who do not respond to even high doses of these drugs even when are administered systemically. Transbronchial biopsies 
and BAL which are performed in patients with steroid-resistant asthma show an increase in eosinophil and Th2-type cytokine (IL-4 and IL-5) level compared to steroid-sensitive patients [48, 49]. The following mechanisms for this phenomenon are postulated [50, 51]: the decrease in the affinity of corticosteroid receptors to corticosteroids (CS) as a result of an increased type $\beta$ CS receptor expression in steroid-resistant patients, reduced CS receptor binding to sensitive nuclear elements or no inhibition of c-Jun N-terminal phosphorylation, or genetic predisposition such as the polymorphism of the gene encoding the corticosteroid receptor, h-GCR/NR3C1. These patients despite the use of CS exhibit local and systemic eosinophilia. Further increase in the CS dose may not provide a measurable clinical effect, but is associated with the risk of serious side effects. Part of the events leading to the development of steroid resistance seems to be reversible and is a potential target for pharmacological intervention.

\section{The impact of omalizumab on eosinophilia in asthma patients in clinical and observational trials as well as in case reports}

In the study by Noga et al. [18], omalizumab therapy significantly reduced the percentage of peripheral eosinophils at the $16^{\text {th }}$ and $52^{\text {nd }}$ week from its commencement. While Tataku et al. [52] observed a significant reduction in the number of eosinophils in induced sputum and FeNO levels after 16 weeks of therapy with omalizumab in patients with severe uncontrolled bronchial asthma.

In Massanari's pooled analysis of five clinical trials [53] on the efficacy of omalizumab in patients with persistent moderate/severe allergic asthma, the post-treatment number of peripheral eosinophils compared to baseline was reduced only in the group of patients receiving omalizumab, with a greater reduction in eosinophil count observed in those in whom the serum free IgE levels were lower than $50 \mathrm{ng} / \mathrm{ml}$. The researchers also found a correlation between the omalizumab-induced decrease in peripheral eosinophils and various clinical parameters, including the occurrence of severe exacerbations, FEV1 value, a response to omalizumab treatment assessed by physicians on GETE (the Global Evaluation of Treatment Effectiveness) scale (correlation between clinical improvement and reduction in the number of eosinophils and between no improvement and increase in the number of eosinophils).

In theEXTRA study conducted by Hanania et al. [54] a clinically significant reduction (by 56\%) in the frequency of severe asthma exacerbations following the treatment with omalizumab was achieved only in the high peripheral eosinophilia group ( $\geq 260 \mathrm{EO} / \mu \mathrm{l}$ ) as compared to the placebo group. A similar effect was observed for FeNO and serum periostin levels, which are considered biomarkers for eosinophilic airway inflammation. Zietkowski et al. [55] also showed a significant decrease in the peripheral eosinophil count, ECP level and FeNO level, which correlated with a decrease in eotaxin levels in the exhaled breath condensate in patients with asthma, who were treated with omalizumab. Whereas Skiepko et al. [56] observed that a decrease in the peripheral eosinophil number by $50 \%$ under the influence of the treatment with omalizumab compared to baseline was associated with a lower frequency of severe exacerbations than in the group with a smaller reduction in the number of eosinophils. The authors of that study indicated that monitoring peripheral eosinophil levels in the course of omalizumab therapy could be a useful marker of response to omalizumab and a predictor of future exacerbations.

Our experience shows that omalizumab is highly effective in patients with allergic asthma and peripheral and tissue hypereosinophilia. The authors described a case of a patient with uncontrolled severe allergic asthma sensitive to house dust mites and Alternaria alternata. with peripheral (1700 Eo/ $\mu \mathrm{l})$ and tissue (in BAL Eo 56\%) hypereosinophilia, in whom the treatment with high doses of inhaled and systemic corticosteroids did not result in normalization of the eosinophil number [57]. Inclusion of omalizumab into the treatment caused a significant improvement in the disease control, with a four-fold reduction in the demand for systemic corticosteroids as well as normalization of peripheral eosinophil count. We observed normalization of eosinophil level during treatment with omalizumab despite the reduction in the daily dose of systemic corticosteroids in another patient suffering from severe uncontrolled allergic asthma with concomitant chronic urticaria and life-threatening angioedema as well as hypersensitivity to non-steroidal anti-inflammatory drugs and hypereosinophilia in peripheral blood [58].

Pelaia et al. [59] showed similar results. They applied omalizumab in five asthma patients with persistent peripheral eosinophilia (mean Eo \% of WBC \pm SD: $15.9 \pm 8.0 \%$; Eo $1588.0 \pm 956.9$ cells/ $\mu$ l) despite long-term treatment with inhaled and systemic corticosteroids. After 16 weeks of treatment with omalizumab, the number of peri- 
pheral eosinophils was almost normalized (mean \pm SD: $6.3 \pm 2.3 \%$ of WBC; absolute numbers: $462.0 \pm 262.3 / \mu \mathrm{l})$ at lowered daily doses of oral corticosteroids. The number of exacerbations also decreased.

These studies and observations show that eosinophilia in the peripheral blood, sputum, BAL and bronchial bioptates may be an important marker for a clinical response to omalizumab. Complete peripheral blood counts with granulocyte differentiation seem to be useful in monitoring the treatment with omalizumab.

\section{Efficacy of omalizumab in syndromes with eosinophilia}

Omalizumab efficacy in eosinophilic inflammation is confirmed by case reports describing syndromes with eosinophilia in which the IgEmediated activation is not a key pathomechanism of the disease nor is involved in the pathomechanism at all. Thus, the beneficial effect of omalizumab action was observed in bronchopulmonary aspergillosis [60, 61], Churg-Strauss syndrome [62, 63], eosinophilic pneumonia [64], Kimura disease [65], eosinophilic otitis media [66], and eosinophilic gastrointestinal syndromes [67].

The authors' experience shows that omalizumab is efficacious in asthma with hypersensitivity to nonsteroidal anti-inflammatory drugs (NSAIDs) accompanied usually by high peripheral and tissue eosinophilia [68]. Asthma in these patients is often severe, even if they avoid using NSAIDs. It is known that the mechanism for NSAID-induced hypersensitivity is IgE-independent and is associated with inhibition of cyclooxygenase-1 (COX-1) and overproduction of leukotrienes. Undoubtedly, eosinophils play a significant role in the development of hypersensitivity and in the clinical picture, being a rich source of cysteinyl leukotrienes [69]. Case reports of patients in whom the tolerance to higher doses of NSAIDs was obtained after the treatment with omalizumab confirm the efficacy of omalizumab in aspirin-induced asthma [70-73].

\section{Mechanisms of omalizumab effect on eosinophils}

Anti-eosinophilic action of omalizumab is manifested by the decrease in the number of eosinophils in peripheral blood and tissues and by the impact on eosinophil survival and functions (Fig. 1). Studies on the mechanism of this action are currently limited to allergic diseases.
It is known that omalizumab does not act directly on eosinophils, but modulates the environment in which they differentiate, migrate, become activated and undergo apoptosis.

High- and low-affinity IgE receptors are found on the surface of eosinophils, thus potentially the reduction in free IgE might be important for functioning and survival of eosinophils in blood and tissues. Immunohistochemical and immunocytochemical studies carried out in patients with allergic diseases showed that the local allergen challenge induces the expression of FceRI on eosinophils infiltrating the respiratory system [74] and skin $[75,76]$. Moreover, the presence of FceRI was also confirmed on peripheral eosinophils in patients with various forms of allergic diseases [77]. In contrast to the presented studies, Seminario et al. [78] were not able to detect FceRI on the surface of eosinophils while observing a large amount of Fc $\varepsilon$ RI $\alpha$ intracellularly, and showed its release to the medium in a form of a soluble receptor. Kita et al. [79] confirmed a low surface expression of FceRI on eosinophils by using the highly sensitive biotin-streptavidin method. In the light of these results, the synthesis of this receptor protein and its expression on the surface of eosinophils seem to be regulated by different mechanisms. Hence, the differences between the results of immunohistochemical examinations evaluating the presence of the protein regardless of the cellular location and the assessment of this receptor expression on the surface of eosinophils were found by using the biotin-streptavidin technique. Functional significance of the FceRI expression on eosinophils poses another problem. In parasitic diseases, the Fce RI activation leads to degranulation of eosinophils and is involved in the cytotoxic response mediated by eosinophils [80]. The role of $F_{c} \varepsilon$ RI on eosinophils in allergic diseases has not been entirely elucidated.

Tomassini et al. [81] conducted an experiment in which they stimulated eosinophils, isolated from allergic patients, with allergens and anti-IgE, anti-IgA and anti-IgG antibodies. Stimulation with specific allergens, to which patients were sensitive, and with anti-IgE antibodies induced the release of EPO but not ECP from eosinophils, anti-IgG stimulation activated eosinophils to release ECP but not EPO, while anti-IgA stimulation released both ECP and EPO from eosinophils. The authors concluded that eosinophils selectively release mediators as a result of stimulation of membrane receptors for immunoglobulins according to their type. Kayaba et al. [82] demonstrated that the IgE-mediated ac- 


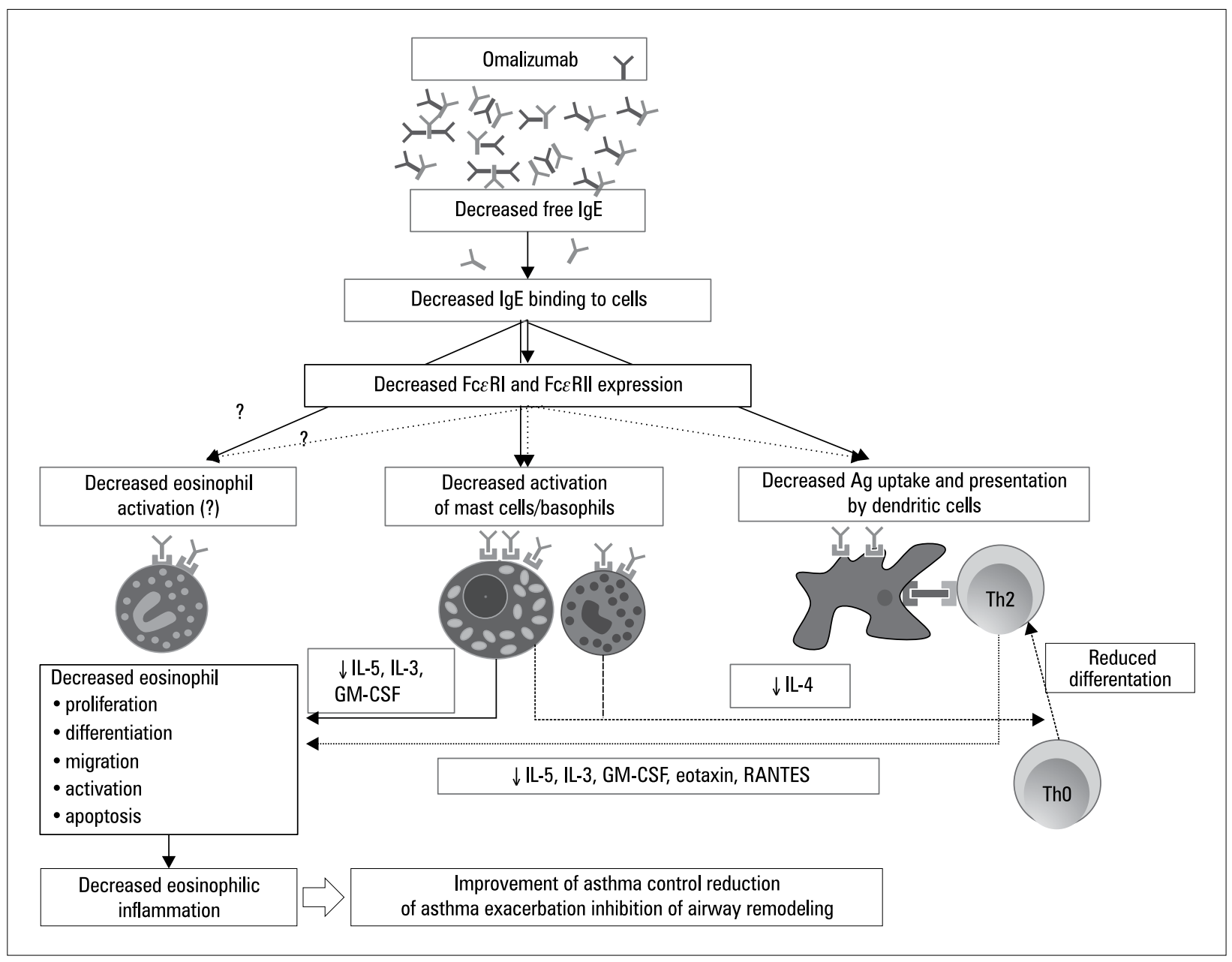

Figure 1. The mechanisms of omalizumab action on eosinophilic inflammation

tivation of eosinophils leads to secretion of IL-10, which may indicate their immunoregulatory role in inflammation. In contrast, Kita et al. [79] did not observe any significant biological effect (degranulation or production of oxygen radicals or release of leukotriene C4) after the FceRI stimulation on eosinophils.

Differences in the response of basophils and eosinophils to stimulation by $F_{c} \varepsilon$ RI may arise from the surface presentation of this receptor. The number of FceRI on eosinophils, as compared to basophils, is several-fold lower (representing approximately $0.5 \%$ ), hence this way of regulation, if of any significance, is rather secondary.

Moreover, research concerning the function of FceRII on eosinophils is ambiguous. Capron et al. [83] observed that the use of anti-CD23 mAb can inhibit IgE-dependent cytotoxicity of eosinophils. Lantero et al. [84] reported that the IgE-mediated stimulation of eosinophils from atopic and non-atopic patients by Fce RII leads to functional changes characterized by the increased migration of eosinophils associated with the increased LFA-1 (lymphocyte function-associated antigen 1) and Mac-1 (macrophage-1 antigen) expression. Arock et al. [85] demonstrated that the activation of Fc RII causes the release of TNF- $\alpha$ by eosinophils, in which the participation of IL-4 is significant. The expression of this receptor depends on the stimulation of IL-3 and GM-CSF [86].

To date, no studies on the effects of omalizumab on the expression and function of these receptors on eosinophils have been performed, however their low expression and the lack of direct relationship between the expression and total IgE level suggest a different mechanism of drug action in eosinophilic inflammation.

In allergic diseases, three major eosinophil activation pathways, the Th-2-dependent, Th1-dependent and associated with the mechanisms of innate immunity, are postulated. The Th-2-dependent pathway, mediated primarily by IL-5, is most important in allergic diseases [87].

Hubner et al. [88] observed that the patients with a clinical response to omalizumab had higher pre-treatment serum IL-5 levels and 
a pronounced decrease in serum IL-5 following omalizumab compared to non-responders. Taka$\mathrm{ku}$ et al. [52] found that the 16-week treatment with omalizumab decreases the production of IL-5 through peripheral mononuclear cells. In contrast, Noga et al. [9] failed to demonstrate the reduction in the number of lymphocytes producing IL-5 in peripheral blood due to the treatment with omalizumab, although Djukanovic et al. [8] reported that the 16-week treatment with omalizumab resulted in the reduction in the number of $\mathrm{CD} 3+, \mathrm{CD} 4+, \mathrm{CD} 8+$ cells in induced sputum and tissue bioptates. Probably, local inhibition of the IL-5 production via Th-2 in the inflamed tissues is of decisive importance. Besides lymphocytes, eosinophils, mast cells and basophils are a rich source of IL-5 [89].

It is known that omalizumab decreases eosinophilia in peripheral blood as well as in the tissues. Chemotactic factors are responsible for the influx of eosinophils to the site of inflammatory reaction. The study by Zietkowki et al. revealed that omalizumab therapy reduces the level of eotaxin [55] and RANTES [90] — strong chemoattractants for eosinophils - in the air exhausted by patients with allergic asthma.

Adhesive molecules displayed on the endothelial cells and eosinophils, including VCAM-1 (vascular cell adhesion molecule 1) and VLA-4 (very late antigen-4), are involved in the migration of eosinophils from blood vessels into the tissues. Their expression is increased by IL-4 and IL-13 [91]. Omalizumab has been found to affect the production of these cytokines [8, 9, 37], thus it can potentially also influence eosinophil diapedesis.

An important element of the persistence of eosinophilic inflammation is impaired eosinophil apoptosis in allergic diseases. Two mechanisms, active and passive, of apoptosis activation in eosinophils have been known. An active mechanism depends on the activation of the Fas receptor, which is universal for the leukocyte population or is associated with the activation of the CD69 receptor. A passive pathway is associated with a decrease in the levels of growth factors for eosinophils, such as IL-3, IL-5 and GM-CSF, in the eosinophil microenvironment [92].

Noga et al. [9] confirmed that omalizumab therapy induces apoptosis in eosinophils, whose marker is annexin V. No changes in 7-amino-actinomycin level (a marker of necrosis) or eosinophil activation CD69 or Fas receptor (CD95) were detected. An increase in eosinophil apoptosis during treatment with omalizumab should therefore be associated with the passive mechanism, which largely depends on the reduction in the level of IL-5 [89] and possibly GM-CSF [9].

In addition to the mentioned above mechanisms, apoptosis is affected by the presence of nitric oxide (NO) in the site of eosinophilic inflammation. NO inhibits apoptosis dependent on the activation of the Fas receptor [93]. Increased levels of NO are observed in asthma, while omalizumab therapy significantly reduces the NO concentration in the exhaled air $[28,34,53$, $55,56]$, which may be important for regression of eosinophilic inflammation in the airways.

\section{Conclusions}

Clinical efficacy of omalizumab has been confirmed in numerous clinical trials. Its pharmacological mechanism of action is more complex than it has been originally thought. In addition to inhibition of the early and late allergic reaction associated with the activation of mast cells and basophils via FceRI, it also affects chronic allergic inflammation, mainly through the reduction in eosinophilic infiltration. Omalizumab impact on eosinophils is indirect through inhibiting the production of proinflammatory cytokines by mast cells, basophils and Th- 2 cells and concerns different stages of the life of these cells from the differentiation in the bone marrow, migration to the tissues, and activation, to apoptosis. Clinical efficacy of omalizumab in asthma has been found to correlate with the level of eosinophils in peripheral blood and the bronchi and with their activity, so this mechanism of action seems to be as important as blocking the IgE-dependent pathway and may be responsible for the efficacy of this drug in non-allergic asthma [94, 95]. The clinical anti-eosinophilic efficacy of omalizumab has been confirmed by case reports on efficacy of therapy with this drug in eosinophilic syndromes not associated with allergic inflammation.

\section{Conflict of interest}

Izabela Kuprys-Lipinska and Piotr Kuna received personal fees for lectures from Novartis and performed clinical studies sponsored by Novartis.

Katarzyna Molinska have no conflict of interest.

\section{References:}

1. Kupryś-Lipińska I, Kuna P. Patofizjologia chorób alergicznych In: Liebhart J (ed.). Choroby alergiczne dorosłych, Medical Tribune 2016: 13-70.

2. Burrows B, Martinez FD, Halonen M, Barbee R.A, Cline MG. Association of asthma with serum IgE levels and skin-test reactivity to allergens. N Engl J Med 1989; 320: 271-277. 
3. Kovac K, Dodig S, Tjesić-Drinković D, Raos M. Correlation between asthma severity and serum IgE in asthmatic children sensitized to Dermatophagoides pteronyssinus. Arch Med Res 2007; 38: 99-105.

4. Carroll WD, Lenney W, Child F et al. Asthma severity and atopy: how clear is the relationship? Arch Dis Child 2006; 91: 405-409.

5. Kuna P, Kupryś-Lipińska I. Omalizumabmonoklonalne przeciwciało anty IgE w leczeniu opornej na standardową terapię astmy. Ordynator Leków 2008; 8: 22-29.

6. Kupryś I, Kuna P. Regulacja syntezy immunoglobuliny E. Post Hig Med Dośw 1997; 51: 651-682.

7. Lowe P, Tannenbaum S, Gautier A, Massanari M, Panahloo Z Omalizumab (Xolair) may normalize IgE production rate in patients with moderate-to-severe atopic asthma. J Allergy Clin Immunol 2009; 123: S152.

8. Djukanović R, Wilson SJ, Kraft M et al. Effects of treatment with anti-immunoglobulin $\mathrm{E}$ antibody omalizumab on airway inflammation in allergic asthma. Am J Respir Crit Care Med 2004; 17: 583-93.

9. Noga O, Hanf G, Brachmann I et al. Effect of omalizumab treatment on peripheral eosinophil and T-lymphocyte function in patients with allergic asthma. J Allergy Clin Immunol 2006; 117: $1493-1499$.

10. Humbert M, Grant JA, Taborda-Barata L et al. High-affinity IgE receptor (FceRI)-bearing cells in bronchial biopsies from atopic and nonatopic asthma. Am J Respir Crit Care Med 1996; 153: 1931-1937.

11. Fregonese L, Patel A, van Schadewijk A et al. Expression of the high-affinity $\mathrm{IgE}$ receptor (FceRI) is increased in fatal asthma. Am J Respir Crit Care Med 2004; 169: A297.

12. Hamelmann E. The rationale for treating allergic asthma with anti-IgE. Eur Respir Rev 2007; 16: 61-66.

13. Lin H, Boesel KM, Griffith DT et al. Omalizumab rapidly decreases nasal allergic response and FcepsilonRI on basophils. J Allergy Clin Immunol 2004; 113: 297-302.

14. MacGlashan DW Jr, Bochner BS, Adelman DC et al. Down-regulation of FcERI expression on human basophils during in vivo treatment of atopic patients with anti-IgE antibody. J Immunol 1997; 158: $1438-1445$.

15. Chanez P, Contin-Bordes C, Garcia G et al. Omalizumab-induced decrease of FceRI expression in patients with severe allergic asthma. Respir Med 2010; 104: 1608-1617.

16. Saini SS, MacGlashan DW Jr, Sterbinsky SA et al. Down-regulation of human basophil IgE and FC epsilon RI alpha surface densities and mediator release by anti-IgE-infusions is reversible in vitro and in vivo. J Immunol 1999; 162: 5624-5630.

17. Noga O, Hanf G, Kunkel G. Immunological and clinical changes in allergic asthmatics following treatment with omalizumab. Int Arch Allergy Immunol 2003; 131: 46-52.

18. Noga O, Hanf G, Kunkel G, Kleine-Tebbe J. Basophil Histamine Release Decreases during Omalizumab Therapy in Allergic Asthmatics. Int Arch Allergy Immunol 2007; 146: 66-70.

19. Pereira Santos MC, Campos Melo A, Caetano A et al. Longitudinal study of the expression of Fce RI and IgE on basophils and dendritic cells in association with basophil function in two patients with severe allergic asthma treated with Omalizumab. Eur Ann Allergy Clin Immunol 2015; 47: 38-40.

20. Hill DA, Siracusa MC, Ruymann KR, Tait Wojno ED, Artis D, Spergel JM. Omalizumab therapy is associated with reduced circulating basophil populations in asthmatic children. Allergy 2014; 69: 674-677.

21. Beck LA, Marcotte GV, MacGlashan D, Togias A, Saini S. Omalizumab-induced reductions in mast cell FceRI expression and function. J Allergy Clin Immunol 2004; 114: 527-530.

22. Prussin C, Griffith DT, Boesel KM, Lin H, Foster B, Casale TB. Omalizumab treatment downregulates dendritic cell Fc $\varepsilon$ RI expression. J Allergy Clin Immunol 2003; 112: 1147-1154.

23. Feuchtinger T, Bartz H, von Berg A et al. Treatment with omalizumab normalizes the number of myeloid dendritic cells during the grass pollen season. J Allergy Clin Immunol 2003; 111: $428-430$.

24. Eggel A, Baravalle G, Hobi G et al. Accelerated dissociation of IgEFceRI complexes by disruptive inhibitors actively desensitizes allergic effector cells. J Allergy Clin Immunol 2014; 133: 1709-1719.
25. Serrano-Candelas E, Martinez-Aranguren R, Valero A et al. Comparable actions of omalizumab on mast cells and basophils. Clin Exp Allergy 2016; 46: 92-102.

26. Boulet LP, Chapman KR, Côté J et al. Inhibitory effects of an anti-IgE antibody E25 on allergen-induced early asthmatic response. Am J Respir Crit Care Med 1997; 155: 1835-1840.

27. Zielen S, Lieb A, De La Motte S et al. Omalizumab protects against allergen-induced bronchoconstriction in allergic (immunoglobulin E-mediated) asthma. Int Arch Allergy Immunol 2013; 160: 102-110.

28. Fahy JV, Fleming HE, Wong $\mathrm{HH}$ et al. The effect of an anti-IgE monoclonal antibody on the early- and late-phase responses to allergen inhalation in asthmatic subjects. Am J Respir Crit Care Med 1997; 155: 1828-1834.

29. van Rensen EL, Evertse CE, van Schadewijk WA et al. Eosinophils in bronchial mucosa of asthmatics after allergen challenge: effect of anti-IgE treatment. Allergy 2009; 64: 72-80.

30. Elishmereni M, Alenius HT, Bradding $\mathrm{P}$ et al. Physical interactions between mast cells and eosinophils: a novel mechanism enhancing eosinophil survival in vitro. Allergy 2011; 66: 376-385

31. Macfarlane AJ, Kon OM, Smith SJ et al. Basophils, eosinophils, and mast cells in atopic and nonatopic asthma and in latephase allergic reactions in the lung and skin. J Allergy Clin Immunol 2000; 105: 99-107.

32. Roth M, Zhong J, Zumkeller C, S'ng CT, Goulet S, Tamm M. The role of IgE-receptors in IgE-dependent airway smooth muscle cell remodelling. PLoS One 2013; 8: e56015. doi: 10.1371/journal.pone.0056015.

33. Zietkowski Z, Skiepko R, Tomasiak-Lozowska MM, Bodzenta-Lukaszyk A. Anti-IgE therapy with omalizumab decreases endothelin-1 in exhaled breath condensate of patients with severe persistent allergic asthma. Respiration 2010; 80: 534-542.

34. Roth M, Zhao F, Zhong J, Lardinois D, Tamm M. Serum IgE induced airway smooth muscle cell remodeling is independent of allergens and is prevented by omalizumab. PLoS One 2015; 10: e0136549 doi: 10.1371/journal.pone.0136549.

35. Roth M, Tamm M. The effects of omalizumab on IgE-induced cytokine synthesis by asthmatic airway smooth muscle cells. Ann Allergy Asthma Immunol 2010; 104: 152-160.

36. Huang YC, Leyko B, Frieri M. Effects of omalizumab and budesonide on markers of inflammation in human bronchial epithelial cells. Ann Allergy Asthma Immunol 2005; 95: $443-451$.

37. Hoshino M, Ohtawa J. Effects of adding omalizumab, an anti-immunoglobulin E antibody, on airway wall thickening in asthma. Respiration 2012; 83: 520-528.

38. Humbert M, Beasley R, Ayres J et al. Benefits of omalizumab as add-on therapy in patients with severe persistent asthma who are inadequately controlled despite best available therapy (GINA 2002 step 4 treatment): INNOVATE. Allergy 2005; 60: 309-316.

39. Humbert M, Ayre G, Fox H, Blogg M. Number needed to treat to prevent one medically significant event per year with addon omalizumab: INNOVATE. XXV EAACI Congress (Vienna, 10-14 June 2006) Abstract Book 2006; 41, 125.

40. Normansell R, Walker S, Milan SJ, Walters EH, Nair P. Omalizumab for asthma in adults and children. Cochrane Database Syst Rev 2014; 1: CD003559 doi: 10.1002/14651858.CD003559.

41. Chipps B, Buhl R, Beeh KM, Fox H, Thomas K, Reisner C. Improvement in quality of life with omalizumab in patients with severe allergic asthma. Curr Med Res Opin 2006; 22: 2201-2208.

42. Kupryś-Lipińska I, Majak P, Molinska J, Kuna P. Effectiveness of the Polish program for the treatment of severe allergic asthma with omalizumab: a single-center.experience. BMC Pulm Med. 2016; 16 : 61 .

43. Global Initiative for Asthma (GINA) 2015. Global Strategy for Asthma Management and Prevention. http://www/ginasthma.org.

44. Schmekel B, Venge P. Markers for eosinophils and T-lymphocytes as predictors of late asthmatic response. Allergy 1993; 48 (17 Suppl): 94-97.

45. Louis R, Lau LC, Bron AO, Roldaan AC, Radermecker M, Djukanovic' $\mathrm{R}$. The relationship between airways inflammation and asthma severity. Am J Respir Crit Care Med 2000; 161: 9-16. 
46. Green RH, Brightling CE, McKenna S et al. Asthma exacerbations and sputum eosinophil counts: a randomised controlled trial. Lancet 2002; 360: 1715-1721.

47. Stone KD, Prussin C, Metcalfe DD. IgE, mast cells, basophils, and eosinophils. J Allergy Clin Immunol 2010; 125 (2 Suppl 2): $\mathrm{S} 73-80$.

48. Leung DYM, Martin RJ, Szefler SJ et al. Dysregulation of interleukin 4 , interleukin 5 , and interferon gamma gene expression in steroid-resistant asthma. J Exp Med 1995; 181: 33-40.

49. Sher E, Leung DYM, Surs W et al. Steroid-resistant asthma. Cellular mechanisms contributing to inadequate response to glucocorticoid therapy. J Clin Invest 1994; 93: 33-39.

50. Panek M, Pietras T, Kupryś-Lipińska I, Górski P, Kuna P, Szemraj J.The analysis of the factors influencing the development of glucocorticoid resistance in the etiopathogenesis of severe bronchial asthma. Postepy Biochem 2010; 56: 373-382.

51. Adcock IM, Lane SJ, Brown CR, Lee TH, Barnes PJ. Abnormal glucocorticoid receptor-activator protein 1 interaction in steroid-resistant asthma. J Exp Med 1995; 182: 1951-1958.

52. Takaku Y, Soma T, Nishihara F et al. Omalizumab attenuates airway inflammation and interleukin-5 production by mononuclear cells in patients with severe allergic asthma. Int Arch Allergy Immunol 2013; 161 (Suppl 2): 107-117.

53. Massanari M, Holgate ST, Busse WW, Jimenez P, Kianifard F, Zeldin R. Effect of omalizumab on peripheral blood eosinophilia in allergic asthma. Respir Med 2010; 104: 188-196.

54. Hanania NA, Wenzel S, Rosén K et al. Exploring the effects of omalizumab in allergic asthma: an analysis of biomarkers in the EXTRA study. Am J Respir Crit Care Med 2013; 187: 804-811.

55. Zietkowski Z, Skiepko R, Tomasiak-Lozowska MM, Bodzenta-Lukaszyk A. Airway inflammation and eotaxin in exhaled breath condensate of patients with severe persistent allergic asthma during omalizumab therapy. Adv Med Sci 2011; 56: 318-322.

56. Skiepko R, Ziętkowski Z, Lukaszyk M et al. Changes in blood eosinophilia during omalizumab therapy as a predictor of asthma exacerbation. Postepy Dermatol Alergol 2014; 31: 305-309.

57. Kupryś-Lipińska I, Kołacińska-Flont M, Marczak J, Górski P, Kurmanowska Z, Kuna P. Effectiveness of omalizumab in an asthmatic patient with severe airway and blood eosinophilia. Postepy Dermatol Alergol 2015; 32: 478-479.

58. Kupryś-Lipińska I, Korczyńska P, Tworek D, Kuna P. Effectiveness of omalizumab in a patient with a life-threatening episode of bronchospasm and larynx angioedema after exposure to house dust. Postepy Dermatol Alergol 2014; 31: 39-44.

59. Pelaia G, Gallelli L, Romeo P et al. Omalizumab decreases exacerbation frequency, oral intake of corticosteroids and peripheral blood eosinophils in atopic patients with uncontrolled asthma. Int J Clin Pharmacol Ther 2011; 49: 713-721.

60. van der Ent CK, Hoekstra H, Rijkers GT. Successful treatment of allergic bronchopulmonary aspergillosis with recombinant anti-IgE antibody. Thorax 2007; 62: 276-277.

61. Collins J, Devos G, Hudes G, Rosenstreich D. Allergic bronchopulmonary aspergillosis treated successfully for one year with omalizumab. J Asthma Allergy 2012; 5: 65-70.

62. Giavina-Bianchi P., Giavina-Bianchi M., Agondi R., Kalil J. Administration of anti-IgE to a Churg-Strauss syndrome patient. Int Arch Allergy Immunol 2007; 144: 155-158.

63. Iglesias E, Camacho Lovillo M, Delgado Pecellín I et al. Successful management of Churg-Strauss syndrome using omalizumab as adjuvant immunomodulatory therapy: First documented pediatric case. Pediatr Pulmonol 2013; 49: E78-81. doi: 10.1002/ppul.22884.

64. Kaya H, Gümüş S, Uçar E et al. Omalizumab as a steroidsparing agent in chronic eosinophilic pneumonia. Chest 2012; 142: $513-516$

65. Nonaka M, Sakitani E, Yoshihara T. Anti-IgE therapy to Kimura's disease: A pilot study. Auris Nasus Larynx 2014; 41: $384-388$.

66. Iino Y, Hara M, Hasegawa $\mathrm{M}$ et al. Clinical efficacy of anti-IgE therapy for eosinophilic otitis media. Otol Neurotol 2012; 33: 1218-1224.

67. Foroughi S, Foster B, Kim N et al. Anti-IgE treatment of eosinophil-associated gastrointestinal disorders. J Allergy Clin Immunol 2007; 120: 594-601.
68. Kuprys-Lipinska I. Majak P, Molinska J, Jonakowski M, Kuna P Comparison of omalizumab therapy effectiveness in patients with hypersensitivity non-steroidal anti-inflammatory drugs (NSAID) and patients who tolerate NSAID (non-NSAID) Polish real life experience. J Allergy Clin Immunol 2016: 137 (Suppl) AB 390.

69. Laidlaw TM, Boyce JA. Aspirin-exacerbated respiratory disease - new prime suspects. N Engl J Med 2016; 374: 484-488.

70. Guillén D, Bobolea I, Calderon O et al. Aspirin desensitization achieved after omalizumab treatment in a patient with aspirin-exacerbated urticaria and respiratory disease. J Investig Allergol Clin Immunol 2015; 25: 133-135.

71. Bergmann KC, Zuberbier T, Church MK. Omalizumab in the treatment of aspirin-exacerbated respiratory disease. J Allergy Clin Immunol Pract 2015; 3: 459-460.

72. Aksu K, Kurt E. Aspirin tolerance following omalizumab therapy in a patient with aspirin-exacerbated respiratory disease. Allergol Immunopathol (Madr) 2013; 41: 208-210.

73. Bobolea I, Barranco P, Fiandor A, Cabañas R, Quirce S. Omalizumab: a potential new therapeutic approach for aspirin-exacerbated respiratory disease. J Investig Allergol Clin Immunol 2010; 20 : 448-449.

74. Rajakulasingam K, Till S, Ying S et al. Increased expression of high affinity IgE (FceRI) receptor-a chain mRNA and proteinbearing eosinophils in human allergen-induced atopic asthma. Am J Respir Crit Care Med 1998; 158: 233-240.

75. Barata LT, Ying S, Grant JA et al. Allergen-induced recruitment of FceRI1 eosinophils in human atopic skin. Eur J Immunol 1997; 27: 1236-1241.

76. Ying S, Barata LT, Meng Q et al. High-affinity immunoglobulin E receptor (FceRI)-bearing eosinophils, mast cells, macrophages and Langerhans' cells in alergen-induced late-phase cutaneous reactions in atopic subjects. Immunology 1998; 93: 281-288.

77. Sihra BS, Kon OM, Grant JA, Kay AB. Expression of high affinity IgE receptors (FceRI) on peripheral blood basophils, monocytes, and eosinophils in atopic and nonatopic subjects: relationship to total serum IgE concentrations. J Allergy Clin Immunol 1997; 99: 699-706.

78. Seminario MC, Saini SS, MacGlashan DW Jr, Bochner BR. Intracellular expression and release of Fc $\varepsilon$ RI $\alpha$ by human eosinophils. J Immunol 1999; 162: 6893-6900.

79. Kita H, Kaneko M, Bartemes KR et al. Does IgE bind to and activate eosinophils from patients with allergy? J Immunol 1999; 162: 6901-6911.

80. Gounni AS1, Lamkhioued B, Ochiai K et al. High-affinity IgE receptor on eosinophils is involved in defence against parasites. Nature 1994; 367: 183-186.

81. Tomassini M, Tsicopoulos A, Tai PC et al. Release of granule proteins by eosinophils from allergic and nonallergic patients with eosinophilia on immunoglobulin-dependent activation. J Allergy Clin Immunol 1991; 88: 365-375.

82. Kayaba H, Dombrowicz D, Woerly G, Papin JP, Loiseau S, Capron M. Human eosinophils and human high affinity IgE receptor transgenic mouse eosinophils express low levels of high affinity IgE receptor, but release IL-10 upon receptor activation. J Immunol 2001; 167: 995-1003.

83. Capron M, Truong MJ, Aldebert D et al. Heterogeneous expression of CD23 epitopes by eosinophils from patients. Relationships with IgE-mediated functions. Eur J Immunol 1991; 21: $2423-2429$.

84. Lantero S, Alessandri G, Spallarossa D, Scarso L, Rossi GA Stimulation of eosinophil IgE low-affinity receptor leads to increased adhesion molecule expression and cell migration. Eur Respir J 2000; 16: 940-946.

85. Arock M, Le Goff L, Bécherel PA, Dugas B, Debré P, Mossalayi MD. Involvement of FC epsilon RII/CD23 and L-arginine dependent pathway in IgE-mediated activation of human eosinophils. Biochem Biophys Res Commun 1994; 203: 265-271.

86. Mawhorter SD, Stephany DA, Ottesen EA, Nutman TB. Identification of surface molecules associated with physiologic activation of eosinophils. Application of whole-blood flow cytometry to eosinophils. J Immunol 1996; 156: 4851-4858.

87. Alam R, Busse WW. The eosinophil - quo vadis? J Allergy Clin Immunol 2004; 113: 38-42. 
88. Hubner M, Korn S, Jung M, Haasler I, Taube Ch, Buhl Rb. Effects of omalizumab on markers of eosinophilic inflammation in patients with severe allergic asthma. Eur Resp J 2011; 38 (Suppl 55): 3352.

89. Varricchi G, Bagnasco D, Borriello F, Heffler E, Canonica GW. Interleukin-5 pathway inhibition in the treatment of eosinophilic respiratory disorders: evidence and unmet needs. Curr Opin Allergy Clin Immunol 2016; 16: 186-200.

90. Zietkowski Z, Skiepko R, Tomasiak-Lozowska MM, Lenczewska D, Bodzenta-Lukaszyk A. RANTES in exhaled breath condensate of patients with severe persistent allergic asthma during omalizumab therapy. Int Arch Allergy Immunol 2011; 154: 25-32.

91. Seminario MC, Bochner BS. Expression and function of beta 1 integrins on human eosinophils. Mem Inst Oswaldo Cruz 1997; 92 (Suppl 2): 157-164.
92. Czarnobilska E, Jakieła B. Zaburzenia apoptozy eozynofilów w etiopatogenezie astmy oskrzelowej. Acta Pneumologica et Allergologica Pediatrica 1998; 2: 21-26.

93. Hebestreit H, Dibbert B, Balatti I et al. Disruption of fas receptor signaling by nitric oxide in eosinophils. J Exp Med 1998; 187: 415-425.

94. Menzella F, Piro R, Facciolongo N, Castagnetti C, Simonazzi A, Zucchi L. Long-term benefits of omalizumab in a patient with severe non-allergic asthma. Allergy Asthma Clin Immunol 2011; 7: 9.

95. Garcia G, Magnan A, Chiron R et al. A proof-of-concept, randomized, controlled trial of omalizumab in patients with severe, difficult-to-control, nonatopic asthma. Chest 2013; 144: 411-419. 